\title{
The Encapsulation Effect on Viability of Mesenchymal Stem Cells
}

\section{(Pengaruh Enkapsulasi Terhadap Viabilitas Sel Punca Mesenkimal)}

\author{
Marsudi Siburian $^{1 *}$, Sismindari $^{2}$, Rilianawati $^{3}$ \\ I*Biomedical Engineering Study Program, Institut Teknologi Sumatera, Lampung, Indonesia. \\ ${ }^{2}$ Department of Pharmaceutical Chemistry, Faculty of Pharmacy, Universitas Gadjah Mada, Yogyakarta, Indonesia. \\ ${ }^{3}$ Center for Pharmaceutical and Medical Technology, Agency for the Assessment and Application of Technology, \\ Tangerang, Indonesia. \\ E-mail: marsudi.siburian@bm.itera.ac.id
}

Article Info:

Received: 30 August 2020

in revised form: 4 November 2020

Accepted: 11 January 2021

Available Online: 1 March 2021

Keywords:

Mesenchymal Stem Cells

Encapsulation

Alginate

Viability

Corresponding Author:

Marsudi Siburian

Biomedical Engineering Study

Program

Institut Teknologi Sumatera

Lampung Selatan

35365

Indonesia

email:

marsudi.siburian@bm.itera.ac.id

\section{ABSTRACT}

Stem cells are potentially used as a regenerative therapy agent. Cell encapsulation is one of the developed methods to utilize Mesenchymal Stem Cells (MSCs) for therapy. This research aimed to study the effect of encapsulation using alginate- $\mathrm{CaCl}_{2}$ towards the viability of hAdMSCs during in vitro culture. Encapsulation of hAdMSCs with alginate- $\mathrm{CaCl}_{2}$ was done using the extrusion method. The viability of hAdMSCs was analyzed with Live/Dead Assay and MTT assay. The results indicated that cultured hAdMSCs within alginate remain alive for seven days culture period. However, the viability was lower than the reference culture. The absorbances from MTT assay of encapsulated MSCs were lower than the conventional hAdMSCs culture. This result indicated hAdMSCs encapsulation with alginate lower the viability of hAdMSCs.

C) (1) (9)
Copyright ( $)$ 2019 JFG-UNTAD
This open access article is distributed under a Creative Commons Attribution (CC-BY-NC-SA) 4.0 International license.

How to cite (APA $6^{\text {th }}$ Style):

Siburian, M. Sismindari., Rilianawati. (2021). The Encapsulation Effect on Viability of Mesenchymal Stem Cells. Jurnal Farmasi Galenika :Galenika Journal of Pharmacy (e-Journal), 7(1), 1-9. doi:10.22487/j24428744.2021.v7.i1.15258 


\section{ABSTRAK}

Sel punca berpotensi untuk dimanfaatkan sebagai agen terapi regeneratif. Enkapsulasi sel adalah salah satu metode yang dikembangkan dalam pemanfaatan Sel Punca Mesenkimal (SPM) untuk terapi. Penelitian ini bertujuan melihat pengaruh enkapsulasi SPM berbasis alginat- $\mathrm{CaCl}_{2}$ terhadap viabilitas dari SPM dalam kultur in vitro. Enkapsulasi SPM dengan alginat- $\mathrm{CaCl}_{2}$ dilakukan dengan menggunakan metode ekstrusi. Pengujian viabilitas SPM dilakukan dengan uji Live/Dead dan uji MTT. Hasil pengujian mengindikasikan SPM didalam alginat tetap hidup selama 7 hari masa kultur. Namun, viabilitasnya lebih rendah dari kultur kontrol. Hasil uji MTT menunjukkan nilai absorbansi dari kultur SPM hasil enkapsulasi lebih rendah dibanding SPM yang dikultur secara konvensional. Hal tersebut menandakan perlambatan aktivitas metabolisme SPM selama dikultur dalam butiran alginat.

Kata kunci: Sel Punca Mesenkimal, Enkapsulasi, Alginat, Viabilitas.

\section{INTRODUCTION}

Stem cells are cells that able to proliferate and differentiate into more than one type of cell. Stem cells are also responsible for the regeneration of damaged tissue or organ. They proliferate and differentiate to replace damaged cells. They also secrete cytokine and growth factors that promote damaged tissue repair (da Silva Meirelles, Fontes, Covas, \& Caplan, 2009; Hassan, Greiser, \& Wang, 2014; Madrigal, Rao, \& Riordan, 2014). Those abilities made stem cells potentially used as an agent for regenerative therapy. Mesenchymal Stem Cell (MSC) is a type of stem cell used in ample research on regenerative therapy. MSCs can be isolated from adult tissues, including human adipose tissue called human adiposederived mesenchymal stem cells (hAdMSC) (Lanza \& Atala, 2014).

Cell encapsulation is one of the developed methodologies to utilize MSCs for therapy, by immobilizing cells inside a semipermeable membrane (Orive et al., 2015). The standard material used for cell encapsulation is alginate. The advantages of using alginate are the easiness to dissolve in water, cheap, biocompatible, and fast to gelate with $\mathrm{Ca}^{2+}$ (Lee \& Mooney, 2012).

In therapy, there are several benefits of using encapsulation on stem cells. Encapsulation can protect stem cells from microenvironment conditions, such as from substances related to oxidative stress and inflammation, and the immune response from the target tissues (Duscher et al., 2016). Encapsulation is also reported to increase the cytokine and growth factor secretion from stem cells (Lee et al., 2014). Despite the benefits, the effect of encapsulation toward the viability of MSCs still needs to be studied. Cells viability is a measure of live cells. It was not restricted to live or death condition and a measure of cellular or metabolic activity (Browne \& Al-Rubeai, 2011; Khan, 2018). Some previous research reported that the viability of mammalian cells increase during culture (Capeling et al., 2019; Lan, Safiejko-Mroczka, \& Starly, 2010; Yao, Zhang, Luan, \& Lin, 2012) while others reported decrement of viability (Ciriza et al., 2018; Li et al., 2018; Markusen et al., 2006; Mohanty, Wu, Chakraborty, Mohanty, \& Ghosh, 2016). Thus, this research will study the effect of encapsulation using alginate$\mathrm{CaCl}_{2}$ towards the viability of hAdMSCs during in vitro culture.

\section{RESEARCH METHOD}

\section{Instrument and Materials}

The instrument used in this research are micropipettes, biosafety cabinet level 2 (ESCO AC2-4E8), syringe, syringe needle 30G, inverted microscope (Leica DMi1), fluorescence microscope (Carl ZaissAxiovert 40 CFL), centrifuge (Thermo Scientific SL 8R), Incubator-CO 2 (ESCO CCL-170B-8), and microplate reader. Materials used in this research are Minimum Essential Medium Eagle - Alpha Modification ( $\alpha$-MEM) (GIBCO), Dulbecco's Modified Eagle Medium (DMEM) (GIBCO), Platelet Rich Plasma (PRP), Heparin (Inviclot), Penisilin/Streptomisin, Alginate-medium viscosity (Sigma Aldrich), $\mathrm{CaCl}_{2}$ (Merck), Trypsin, EDTA, 4-(2-hydroxyethyl)-1-piperazineethanesulfonic acid (HEPES), 3-(4,5-dimethylthiazol-2-yl)-2,5-diphenyltetrazolium bromide (MTT) (Invitrogen), sodium 
dodecyl sulfate (SDS) (Sigma Aldrich), phosphate-buffered saline (PBS), natrium chloride (NaCl), Propidium Iodide (Life Technologies), and Calcein-AM (Invitrogen).

\section{Culture of hAdMSCs (Two-Dimension Culture)}

Human adipose-derived MSCs were cultured in $\alpha$-MEM supplemented with 5\% PRP, $1 \%$ Penicillin/Streptomycin, and 1\% Heparin (Riis, Nielsen, Pennisi, Zachar, \& Fink, 2016). The cells were incubated at $37^{\circ} \mathrm{C}$ and $5 \% \mathrm{CO}_{2}$. The culture medium was refreshed every 3 days. Morphology of cells observed daily using an inverted microscope and subcultured at the confluence.

\section{Encapsulation of hAdMSCs (Three-Dimension Culture)}

Culture of hAdMSCs was trypsinized, counted using a hemocytometer, and resuspended in $\alpha$-MEM. A solution of alginate was prepared in $\mathrm{NaCl} 0,9 \%$ and mixed with a suspension of hAdMSCs, the final concentration of alginate solution was 1,75\% (Mohanty et al., 2016). The mixture of alginate and hAdMSCs was put in a syringe and extruded through a 30G syringe needle into a solution of $200 \mathrm{mM}$ $\mathrm{CaCl}_{2}$. After 10 minutes, alginate beads were washed 3 times with $\mathrm{NaCl} 0,9 \%$ and plated in tissue culture dish filled with culture medium. The alginate beads were incubated at $37^{\circ} \mathrm{C}$ and $5 \% \mathrm{CO}_{2}$. The culture medium was refreshed every 3 days. Morphology of cells and beads were observed with an inverted microscope for 7 days.

\section{Decapsulation}

To release the hAdMSCs from the alginate bead, alginate beads were immersed in $2 \mathrm{~mL}$ of decapsulation mixture (50 mM EDTA + $10 \mathrm{mM}$ HEPES in PBS) at room temperature. After 10 minutes, hAdMSCs were pelleted by centrifugation at $1.200 \mathrm{rpm}$ for 5 minutes and resuspended in DMEM (Kim, Sachdev, \& Sidhu, 2013).

\section{Live/Dead Viability Assay}

The life/dead viability assay reagent consists of Propidium Iodide and Calcein-AM (PI-Cal reagent). Alginate beads or $100 \mu \mathrm{L}$ cells suspension obtained from the culture of hAdMSCs or decapsulation step was transferred into a microplate 96-well, added with $100 \mu \mathrm{L}$ PI-Cal reagent (PI $10 \mu \mathrm{L} / \mathrm{mL}+$ Calcein $2 \mu \mathrm{L} / \mathrm{mL}$ in PBS), and incubated at $37^{\circ} \mathrm{C}$ and $5 \% \mathrm{CO}_{2}$ for 30 minutes. The samples were then observed using a fluorescence microscope at the excitation wavelength of $490 \pm 10 \mathrm{~nm}$ (Molecular Probes, 2005).

\section{MTT assay}

$100 \mu \mathrm{L}$ of hAdMSCs or decapsulated hAdMSCs suspension culture were transferred into 96-well plate, and $100 \mu \mathrm{L}$ MTT solutions $(0,5 \mathrm{mg}$ MTT/mL) was added into the wells. The microplate was protected from light exposure and incubated in $37^{\circ} \mathrm{C}, 5 \% \mathrm{CO}_{2}$ (Riss et al., 2004). After 18 hours incubation, 100 $\mu \mathrm{L}$ SDS $10 \%$ was added into each well and re-incubated overnight at room temperature. Formazan images were captured using an inverted microscope, and absorbances were measured using ELISA reader at $595 \mathrm{~nm}$. This experiment was performed in triplicate.

$$
\text { Viability }=\frac{(\text { sample absorbance })}{(\text { control or reference absorbance })} \times 100 \%
$$

\section{Data Analysis}

Data Analysis was conducted using software IBM SPSS Statistics 23. Data were analyzed using the normality test to see the distribution of data. Normally distributed data will be analyzed with Independent-Samples T-Test, with a confidence interval of $95 \%$, to see the difference between groups (Dahlan, 2018). 


\section{RESULTS AND DISCUSSION}

\section{Morphology of Cultured hAdMSCs}

The culture methods of hAdMSCs in this research can be distinguished into two methods. There were two-dimension (2D) culture and three-dimension (3D) culture. In 2D culture, hAdMSCs are grown directly in culture containers such as tissue culture dish or flask. The hAdMSCs will grow and coat the surface of culture containers made of polystyrene. This method is the conventional method in cell culture. The 3D culture method was developed to increase the resemblance of in vitro culture cells with the condition of cells in vivo (Joseph, Malindisa, \& Ntwasa, 2019). In this research, the 3D culture method was performed by encapsulating hAdMSCs. Alginate encapsulated hAdMSCs were cultured inside culture dish. hAdMSCs from 2D culture used as a reference for hAdMSCs from 3D culture.

The shape of hAdMSCs from the 3D culture was round (Figure 1c, 1d). It was different from the characteristics of hAdMSCs from 2D culture (Figure 1a, 1b). The characteristics of in vitro cultured MSCs were spindles-shaped or elongated with size ranging from 5 to $40 \mu \mathrm{m}$ (Ryu, Cho, Lee, Choi, \& Cho, 2013). These characteristics corresponded to hAdMSCs that cultured with the $2 \mathrm{D}$ culture method. However, the observed shape of hAdMSCs from 3D culture is similar to encapsulated bone marrow mesenchymal stem cells (BMMSC). After 3 days of culture, the observed shape of BMMSCs was round (Markusen et al., 2006).

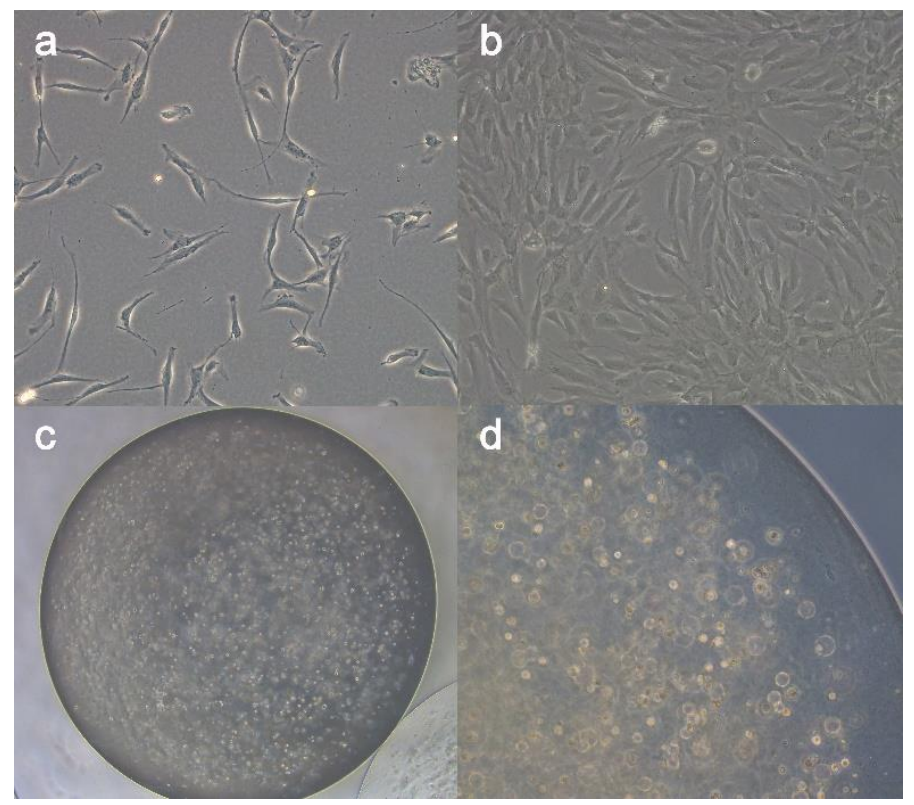

Figure 1. Mesenchymal Stem Cells during culture. a, b 2D-cultured hAdMSCs at day 1 dan 5 (magnfication 100x). c day-1 3D-cultured hAdMSCs inside alginate (magnification 40x). d day-5 3D-cultured hAdMSCs (magnification 100x).

This morphologic difference, between 2D and 3D culture hAdMSCs, might be caused by the inability of hAdMSCs to attached to alginate. Attachment of cells into culture containers, such as polystyrene, will trigger morphologic alteration. Attached cells will undergo cytoskeleton reorganization and turned cells flatter (Khalili \& Ahmad, 2015). Mammalian cells, including hAdMSCs, were known to lack membrane receptors for alginate. It made hAdMSCs unable to interacted or attached with alginate (Lee \& Mooney, 2001; Pokrywczynska, Drewa, Jundzill, \& Lysik, 2008). Furthermore, the net charge of membrane cell was neutral while alginate was negatively charged; thus there was no tendency to form ionic bonds (J. Boohaker, W. Lee, Vishnubhotla, M. Perez, \& R. Khaled, 2012; Shinde \& Nagarsenker, 2009). 


\section{Viability of MSCs}

Live/Dead Viability Assay was conducted to figure the encapsulation effect on the viability of hAdMSCs. This method was able to differentiate dead cells from living cells. Propidium Iodide (PI) in the reagent can enter the dead cell through the damaged membrane. PI will intercalate with DNA which produces red fluorescence, making dead cells observed in red colour (Figure 2a). The other component of reagent, Calcein-AM, was able to pass through the membrane of living cells. It was converted into calcein by intracellular esterase, which gives green fluorescence (Figure 2b, 2c) (Poulsen, Culbertson, Jacobson, \& Ramsey, 2005). Figure $2 \mathrm{e}$ and $2 \mathrm{f}$ showed green fluorescence inside the alginate. It means hAdMSCs remained viable during 7 days of culture. Dead hAdMSCs inside alginate will appear as a red dot in Figure 2d; this was Live/Dead viability result for 3D cultured hAdMSCs that incubated in $4^{\circ} \mathrm{C}$ for 7 days.

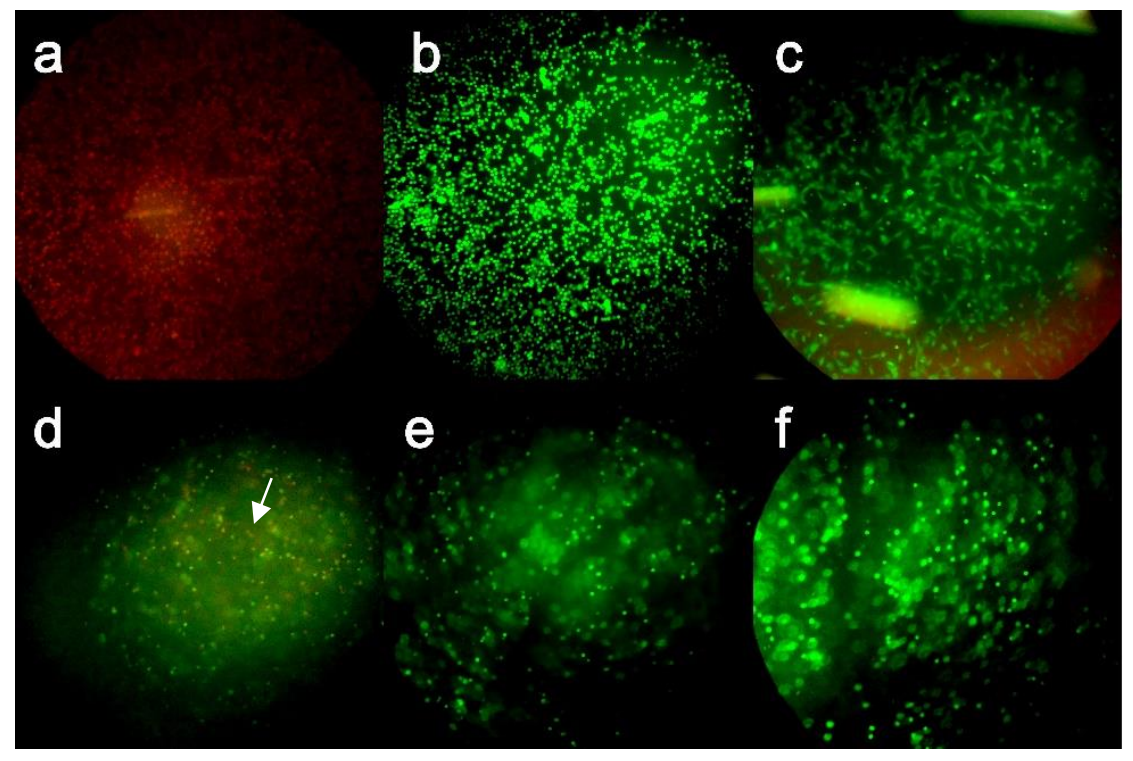

Figure 2. hAdMSCs stained with PI-Calcein. Result for 2D-cultured: a dead control cells, b control live cells, c Day 2 culture of hAdMSCs. Result for 3D-cultured: $\mathbf{d}$ dead hAdMSCs (red dot) in alginate bead; e, $\mathbf{f}$ Day 1 and 7 of the culture of hAdMSCs inside alginate bead.

In addition to Live-Dead Viability Assay, the viability of hAdMSCs also tested using the MTT method. This method tested the viability of mammalian cells based on their metabolic activity. Metabolic activity is determined by measuring dehydrogenase, reducing activity on tetrazolium salt (Mosmann, 1983). Dehydrogenase of viable cells with active metabolism will convert MTT into purple formazan crystal while dead cells cannot convert MTT (Riss et al., 2004). The amount of formed formazan crystal was measured at $595 \mathrm{~nm}$ and shown as absorbance number. As preparation for MTT assay, the incubation time was determined. Incubation time is the time needed by hAdMSCs to reduce MTT into formazan crystal. We found that hAdMSCs cultured with 2D method needs 4 hours to formed formazan crystal which some of them had an equal or bigger size than the size of the cells (Figure 3a). Therefore 4 hours was determined as the incubation time for MTT assay. 


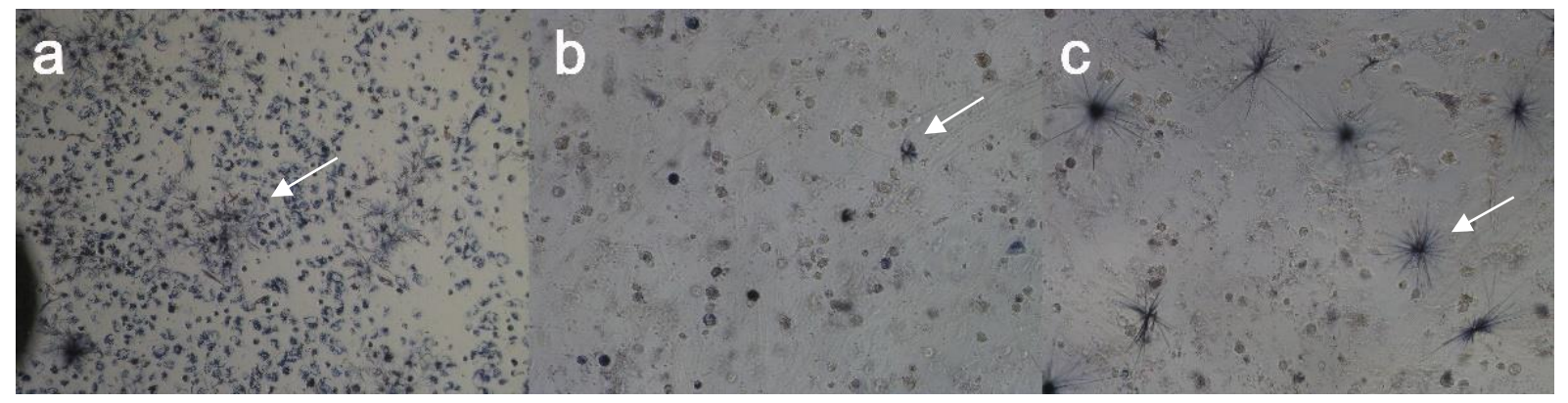

Figure 3. Formazan crystal appearance in MTT assay after incubation. a 2D-cultured hAdMSCs after $4 \mathrm{hr}$ of incubation (magnification 40x). b 3D-cultured hAdMSCs after $4 \mathrm{hr}$ of incubation (magnification 100x). c 3D-cultured hAdMSCs after overnight incubation (magnification 100x).

However, incubation of 3D cultured hAdMSCs for 4 hours resulted in fewer or smaller formazan crystal than $2 \mathrm{D}$ cultured hAdMSCs. The formazan crystal size was the same or smaller than the cells (Figure $3 b$ ). To acquire the same crystal size with ones from $2 \mathrm{D}$ culture, the incubation time was needed to be extended until 18 hours (Figure 3c). The difference of incubation time between hAdMSCs from different culture methods might be related to differences in cells' ability to reduce MTT. It might be caused by alteration of the culture condition, which affects the metabolic activity and then reduces or improves cells' ability to convert MTT to formazan. Affected test result by a change in metabolism due to the treatment given to cells is already known as the MTT method's limitation (Maioli et al., 2009; Rai et al., 2018; Riss et al., 2004).

The viability difference of hAdMSCs was also shown in the measured absorbance value. The initial number of cells in both culture condition was equal. The absorbance value for hAdMSCs from 2D culture was significantly higher, $p_{\text {value }}<0.05$, than the $3 \mathrm{D}$ cultured (Figure 4 ). At day one, the absorbance value were $0,673 \pm 0,027$ and $0,326 \pm 0,006$, respectively. It means the viability of $3 \mathrm{D}$ cultured hAdMSCs was $48,49 \%$ if compared to 2D cultured hAdMSCs absorbances. This result indicates a lower amount of formed formazan crystal in the 3D cultured hAdMSCs. Therefore supports the possibility of decreased ability of 3D cultured hAdMSCs to reduce MTT. It might be caused by metabolic deceleration or reduction of proliferation in the $3 \mathrm{D}$ cultured cells.

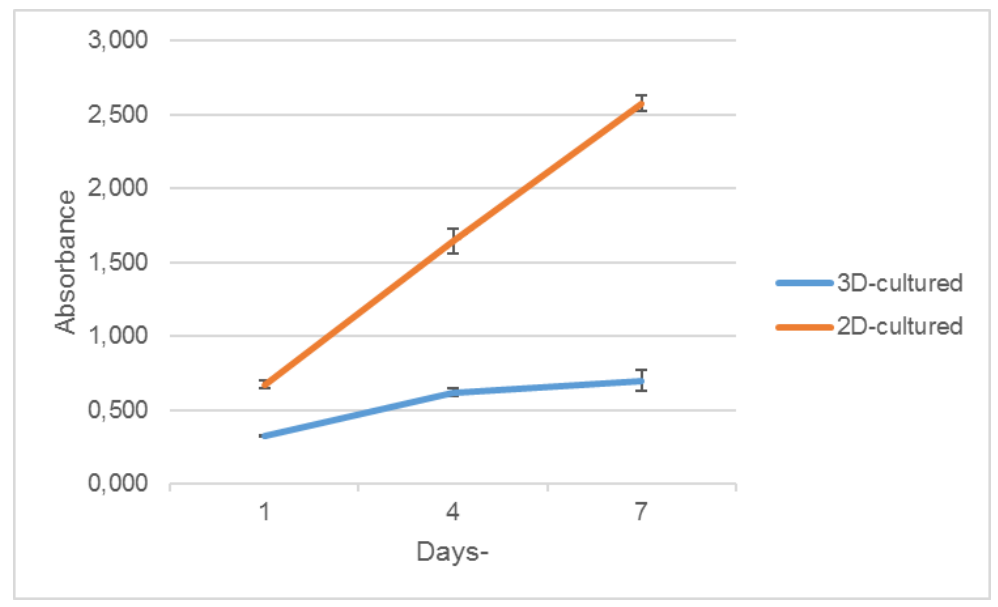

Figure 4. The result of MTT assay in 2D and 3D-cultured hAdMSCs. Both cultures have the same initial cell number. The steeper curve of absorbances indicated a higher proliferation rate and metabolic activity.

On days 4 and 7, there was an increase in absorbance value from 2D cultured hAdMSCs. It indicated an increased number of cells as a result of the proliferation of hAdMSCs. Compared to 2D cultured, the 
increase in the absorbance value of 3D cultured is lower; thus, the viability was lower. The viability for day 4 and 7 were $37,61 \%$ and $27,13 \%$, respectively. There were two possible causes for this. The first one was due to a lower proliferation rate of 3D cultured hAdMSCs. Lower proliferation rate means a lower number of cells and results in lower absorbances. Furthermore, the second cause was hAdMSCs have adapted to its culture environment, which made cells' metabolism much more active. The metabolism of cells decreased during the early adaptation stage when introduced to a new culture environment (Ho \& Zhang, 2018).

There were several culture condition changes in this research. Those were the changes from 2D to 3D culture, the inability of cells to attach into its growth medium, and the presence of $\mathrm{CaCl}_{2}$. The change of culture condition from 2D to 3D culture method affects the metabolism of cells. The use of encapsulation, as one of the 3D culture method, in culturing murine MSCs and epidermal stem cells reported to lower the viability of the MSCs (Ciriza et al., 2018; Li et al., 2018). The effect becomes more visible when accompanied by the inability of cells to attach into culture container. The proliferation of encapsulated MSCs in alginate was slower than encapsulated MSCs in alginate-gelatin (Yao et al., 2012) or even not proliferated and having a decrease in cell number (Mohanty et al., 2016). Changes in metabolic activity were also reported to occur during cell encapsulation in alginate; those were a decreased rate of glycolysis and citric acid cycle and an increase in insulin secretion (Simpson, Stabler, Simpson, Sambanis, \& Constantinidis, 2004). Differ with encapsulation of cells, the encapsulation of islet had no significant effect on gene expression or transcriptomic profile of islet (Vaithilingam et al., 2011) and the encapsulation of organoid was also reported to have an increase in proliferation (Capeling et al., 2019). The cells' ability to attach into gelatine or to other cells when encapsulated in forms of cells aggregate or islet made this difference. Those results showed that metabolic alteration was more pronounced when 3D cultured cells could not attach during culture. The ability of cells to attached into culture container affect the communication and regulation of cells. It affects the expression of receptors in the cells membrane, which affect the expression or reception of signals. Thus, affect the cycle, migration, proliferation, and differentiation of cells (Khalili \& Ahmad, 2015).

Change in the concentration of $\mathrm{Ca}^{2+}$ can affect the ion $\mathrm{Ca}^{2+}$ equilibrium of cells. The change in ion balance will disturb the cell cycle and direct cells to enter cell cycle arrest and move into quiescent or even apoptosis (Humeau et al., 2018). However, Alginate encapsulation can protect cells and retain cell viability almost as high as when it is cultured in medium without $\mathrm{CaCl}_{2}(\mathrm{Cao}$, Chen, \& Schreyer, 2012). Thereby, the viability change in encapsulated hAdMSCs was more likely to be caused by the inability to attach during culture.

\section{CONCLUSION}

The presented results showed that hAdMSCs were viable for 7 days of culture inside the alginate bead. The viability of 3D cultured hAdMSCs was lower than 2D culture hAdMSCs, and keep decreasing as culture proceed. It is suspected to have a lower proliferation rate and lower metabolic activity due to its inability to attach to alginate. Further research on metabolomic, proteomic, and cell cycle of encapsulated MSCs is still needed for the utilization of encapsulated hAdMSCs in regenerative therapy.

\section{REFERENCES}

Browne, S. M., \& Al-Rubeai, M. (2011). Defining viability in mammalian cell cultures. Biotechnology Letters, 33(9), 1745-1749. https://doi.org/10.1007/s10529-011-0644-2

Cao, N., Chen, X. B., \& Schreyer, D. J. (2012). Influence of Calcium Ions on Cell Survival and Proliferation in the Context of an Alginate Hydrogel. ISRN Chemical Engineering, 2012, 1-9. https://doi.org/10.5402/2012/516461

Capeling, M. M., Czerwinski, M., Huang, S., Tsai, Y.-H., Wu, A., Nagy, M. S., ... Spence, J. R. (2019). Nonadhesive Alginate Hydrogels Support Growth of Pluripotent Stem Cell-Derived Intestinal $\begin{array}{lllll}\text { Organoids. Stem } \quad \text { Cell } & \text { Reports, } & \text { 381-394. }\end{array}$ https://doi.org/https://doi.org/10.1016/j.stemcr.2018.12.001 
Ciriza, J., Del Burgo, L. S., Gurruchaga, H., Borras, F. E., Franquesa, M., Orive, G., ... Pedraz, J. L. (2018). Graphene oxide enhances alginate encapsulated cells viability and functionality while not affecting the foreign body response. Drug Delivery, 25(1), 1147-1160. https://doi.org/10.1080/10717544.2018.1474966

da Silva Meirelles, L., Fontes, A. M., Covas, D. T., \& Caplan, A. I. (2009). Mechanisms involved in the therapeutic properties of mesenchymal stem cells. Cytokine and Growth Factor Reviews, 20(5-6), 419-427. https://doi.org/10.1016/j.cytogfr.2009.10.002

Dahlan, S. M. (2018). Statistik untuk kedokteran dan kesehatan (5th ed.). Jakarta: Salemba Medica.

Duscher, D., Barrera, J., Wong, V. W., Maan, Z. N., Whittam, A. J., Januszyk, M., \& Gurtner, G. C. (2016). Stem Cells in Wound Healing: The Future of Regenerative Medicine? A Mini-Review. Gerontology, 62(2), 216-225. https://doi.org/10.1159/000381877

Hassan, W. U., Greiser, U., \& Wang, W. (2014). Role of adipose-derived stem cells in wound healing. Wound Repair and Regeneration, 22(3), 313-325. https://doi.org/10.1111/wrr.12173

Ho, W. C., \& Zhang, J. (2018). Evolutionary adaptations to new environments generally reverse plastic phenotypic changes. Nature Communications, 9(1), 1-11. https://doi.org/10.1038/s41467-01702724-5

Humeau, J., Bravo-San Pedro, J. M., Vitale, I., Nuñez, L., Villalobos, C., Kroemer, G., \& Senovilla, L. (2018). Calcium signaling and cell cycle: Progression or death. Cell Calcium, 70, 3-15. https://doi.org/10.1016/j.ceca.2017.07.006

J. Boohaker, R., W. Lee, M., Vishnubhotla, P., M. Perez, J. L., \& R. Khaled, A. (2012). The Use of Therapeutic Peptides to Target and to Kill Cancer Cells. Current Medicinal Chemistry, 19(22), 3794-3804. https://doi.org/10.2174/092986712801661004

Khalili, A. A., \& Ahmad, M. R. (2015). A Review of cell adhesion studies for biomedical and biological applications. International Journal of Molecular Sciences, 16(8), 18149-18184. https://doi.org/10.3390/ijms160818149

Khan, Y. (2018). Characterizing the properties of tissue constructs for regenerative engineering. Encyclopedia of Biomedical Engineering (Vol. 1-3). Elsevier. https://doi.org/10.1016/B978-0-12801238-3.99897-0

Kim, J., Sachdev, P., \& Sidhu, K. (2013). Alginate microcapsule as a 3D platform for the efficient differentiation of human embryonic stem cells to dopamine neurons. Stem Cell Research, 11(3), 978-989. https://doi.org/10.1016/j.scr.2013.06.005

Lan, S. F., Safiejko-Mroczka, B., \& Starly, B. (2010). Long-term cultivation of HepG2 liver cells encapsulated in alginate hydrogels: A study of cell viability, morphology and drug metabolism. Toxicology in Vitro, 24(4), 1314-1323. https://doi.org/10.1016/j.tiv.2010.02.015

Lanza, R., \& Atala, A. (2014). Essentials of Stem Cell Biology. Essentials of Stem Cell Biology, 307327. https://doi.org/10.1016/B978-0-12-374729-7.00036-6

Lee, C., Nicolini, A., Watkins, E., Burnsed, O., Boyan, B., \& Schwartz, Z. (2014). Adipose Stem Cell Microbeads as Production Sources for Chondrogenic Growth Factors. Journal of Stem Cells and Regenerative Medicine, 10(2), 38-48.

Lee, K. Y., \& Mooney, D. J. (2001). Hydrogels for tissue engineering. Chemical Reviews, 101(7), 18691879. https://doi.org/10.1021/cr000108x

Lee, K. Y., \& Mooney, D. J. (2012). Alginate: Properties and biomedical applications. Progress in Polymer Science (Oxford), 37(1), 106-126. https://doi.org/10.1016/j.progpolymsci.2011.06.003

Li, Z., Huang, S., Liu, Y., Yao, B., Hu, T., Shi, H., ... Fu, X. (2018). Tuning Alginate-Gelatin Bioink Properties by Varying Solvent and Their Impact on Stem Cell Behavior. Scientific Reports, 8(1), 1-8. https://doi.org/10.1038/s41598-018-26407-3

Madrigal, M., Rao, K. S., \& Riordan, N. H. (2014). A review of therapeutic effects of mesenchymal stem cell secretions and induction of secretory modification by different culture methods. Journal of Translational Medicine, 12(1), 1-14. https://doi.org/10.1186/s12967-014-0260-8

Maioli, E., Torricelli, C., Fortino, V., Carlucci, F., Tommassini, V., \& Pacini, A. (2009). Critical appraisal of the MTT assay in the presence of Rottlerin and uncouplers. Biological Procedures Online, 11(1), 227-240. https://doi.org/10.1007/s12575-009-9020-1 
Markusen, J. F., Mason, C., Hull, D. A., Town, M. A., Tabor, A. B., Clements, M., ... Dunnill, P. (2006). Behavior of adult human mesenchymal stem cells entrapped in alginate-GRGDY beads. Tissue Engineering, 12(4), 821-830. https://doi.org/10.1089/ten.2006.12.821

Mohanty, S., Wu, Y., Chakraborty, N., Mohanty, P., \& Ghosh, G. (2016). Impact of alginate concentration on the viability, cryostorage, and angiogenic activity of encapsulated fibroblasts. Materials Science and Engineering C, 65, 269-277. https://doi.org/10.1016/j.msec.2016.04.055

Molecular Probes. (2005). LIVE/DEAD ® Viability/Cytotoxicity Kit* for mammalian cells*. Retrieved October 3, 2020, from https://assets.thermofisher.com/TFS-Assets/LSG/manuals/mp03224.pdf

Mosmann, T. (1983). Rapid colorimetric assay for cellular growth and survival: Application to proliferation and cytotoxicity assays. Journal of Immunological Methods, 65(1-2), 55-63. https://doi.org/10.1016/0022-1759(83)90303-4

Orive, G., Santos, E., Poncelet, D., Hernández, R. M., Pedraz, J. L., Wahlberg, L. U., ... Emerich, D. (2015). Cell encapsulation: technical and clinical advances. Trends in Pharmacological Sciences, 36(8), 537-546. https://doi.org/10.1016/j.tips.2015.05.003

Pokrywczynska, M., Drewa, T., Jundzill, A., \& Lysik, J. (2008). Alginate Is Not a Good Material for Growth of Rapidly Proliferating Cells. Transplantation Proceedings, 40(5), 1664-1667. https://doi.org/10.1016/j.transproceed.2008.03.135

Poulsen, C. R., Culbertson, C. T., Jacobson, S. C., \& Ramsey, J. M. (2005). Static and dynamic acute cytotoxicity assays on microfluidic devices. Analytical Chemistry, 77(2), 667-672. https://doi.org/10.1021/ac049279i

Rai, Y., Pathak, R., Kumari, N., Sah, D. K., Pandey, S., Kalra, N., ... Bhatt, A. N. (2018). Mitochondrial biogenesis and metabolic hyperactivation limits the application of MTT assay in the estimation of radiation induced growth inhibition. Scientific Reports, 8(1), 1-15. https://doi.org/10.1038/s41598-018-19930-w

Riis, S., Nielsen, F. M., Pennisi, C. P., Zachar, V., \& Fink, T. (2016). Comparative Analysis of Media and Supplements on Initiation and Expansion of Adipose-Derived Stem Cells. Stemcells Translational Medicine, 5, 314-324. https://doi.org/http://dx.doi.org/ 10.5966/sctm.2015-0148

Riss, T. L., Moravec, R. A., Niles, A. L., Duellman, S., Benink, H. A., Worzella, T. J., \& Minor, L. (2004). Cell Viability Assays. Assay Guidance Manual, (Md), 1-25. Retrieved from http://www.ncbi.nlm.nih.gov/pubmed/23805433

Ryu, Y. J., Cho, T. J., Lee, D. S., Choi, J. Y., \& Cho, J. (2013). Phenotypic characterization and in vivo localization of human adipose-derived mesenchymal stem cells. Molecules and Cells, 35(6), 557564. https://doi.org/10.1007/s10059-013-0112-z

Saji Joseph, J., Tebogo Malindisa, S., \& Ntwasa, M. (2019). Two-Dimensional (2D) and ThreeDimensional (3D) Cell Culturing in Drug Discovery. Cell Culture. https://doi.org/10.5772/intechopen.81552

Shinde, U., \& Nagarsenker, M. (2009). Characterization of gelatin-sodium alginate complex coacervation system. Indian Journal of Pharmaceutical Sciences, (June), 313-317.

Simpson, N. E., Stabler, C. L., Simpson, C. P., Sambanis, A., \& Constantinidis, I. (2004). The role of the $\mathrm{CaCl} 2$-guluronic acid interaction on alginate encapsulated $\beta \mathrm{TC} 3$ cells. Biomaterials, 25(13), 2603-2610. https://doi.org/10.1016/j.biomaterials.2003.09.046

Vaithilingam, V., Quayum, N., Joglekar, M. V., Jensen, J., Hardikar, A. A., Oberholzer, J., ... Tuch, B. E. (2011). Effect of alginate encapsulation on the cellular transcriptome of human islets. Biomaterials, 32(33), 8416-8425. https://doi.org/10.1016/j.biomaterials.2011.06.044

Yao, R., Zhang, R., Luan, J., \& Lin, F. (2012). Alginate and alginate/gelatin microspheres for human adipose-derived stem cell encapsulation and differentiation. Biofabrication, 4(2). https://doi.org/10.1088/1758-5082/4/2/025007 